\title{
Four New Tetracyclic Alkaloids with cis-decahydroquinoline Motif from Myrioneuron effusum
}

Jia-Hui Zhang a, b, Jing-Jing Guo c, Yu-Xi Yuan ${ }^{\text {c, }}$ Yan-Hui Fu ${ }^{\text {d, }}$ Yu-Cheng Gu ${ }^{\text {e }}$, Yu Zhang a ${ }^{\text {a }}$ Duo-Zhi Chen a, Shun-Lin Li a, Ying-Tong $\mathrm{Di}^{\text {*, a }}$, and Xiao-Jiang Hao *, a

${ }^{a}$ State Key Laboratory of Phytochemistry and Plant Resources in West China, Kunming Institute of Botany, Chinese Academy of Sciences, Kunming 650201, Yunnan, P. R. China.

${ }^{\mathrm{b}}$ University of Chinese Academy of Sciences, Beijing 100049, P. R. China.

${ }^{c}$ Yunnan University of TCM, Kunming 650500, Yunnan, P. R. China.

${ }^{\mathrm{d}}$ Hainan normal University, Haikou 571158, Hainan, P. R. China.

e Syngenta, Jealott's Hill International Research Centre, Bracknell, Berkshire RG42 6EY, UK

* To whom correspondence should be addressed. Tel: +86-871-65223263. Fax: +86-871-65223070.

E-mail: haoxj@mail.kib.ac.cn; diyt@mail.kib.ac.cn 


\begin{abstract}
:
Four new Myrioneuron alkaloids, mysumamides A-D (1-4), along with three known ones were isolated from the twigs and leaves of Myrioneuron effusum. All of these alkaloids possessed the tetracyclic skeleton and contained the decahydroquinoline (cis-DHQ) moiety. Their structures and relative configurations were elucidated on the basis of spectroscopic methods, especially 2D NMR techniques. The absolute configuration of 1 was determined by single-crystal X-ray diffraction. The cytotoxic activities of these compounds were also evaluated in vitro.
\end{abstract}

\title{
Chemical compounds studied in this article
}

Myrionamide (PubChem CID: 25105510); Schoberine (PubChem CID: 7278936); Myrionidine (PubChem CID: 25067255)

Keywords: Rubiaceae, Myrioneuron effusum, alkaloids, mysumamides A-D. 


\section{Introduction}

Myrioneuron alkaloids elaborated specifically by plants of the genus Myrioneuron R. Br. (Rubiaceae) belong to the category of lysine-based structurally diverse natural products with various polycyclic skeletons (tricyclic-, tetracyclic-, pentacyclic-, hexacyclic-, octacyclic, and decacyclic-type), which have attracted much attention regarding their bioactivity and total synthesis [1-13]. In the past several years, we have isolated eighteen structurally unique and biosynthetically meaningful Myrioneuron alkaloids, including some with significant anti-hepatitis $\mathrm{C}$ virus (HCV) and antimicrobial activities [7-12]. In our continuing search for structurally unique and biologically active compounds, four new Myrioneuron alkaloids with cis-DHQ motif, mysumamides A-D (1-4) as well as three known ones, myrionamide (5), schoberine (6), and myrionidine (7) were isolated from the twigs and leaves of M. effusum (Pitard) Li. Herein, we presented the isolation, structural elucidation, and bioactivity evaluation of these compounds.

\section{Experimental}

\subsection{General experimental procedures}

Optical rotations were measured with a Jasco P-1020 polarimeter. UV spectra were obtained using a Shimadzu UV-2401A spectrophotometer. A Tenor 27 spectrophotometer was used for IR spectra as $\mathrm{KBr}$ pellets. 1D and 2D NMR spectra were recorded on Bruker spectrometer with TMS as internal standard. HRESIMS was performed on a triple quadrupole mass spectrometer. Semi-preparative HPLC was performed on an Agilent 1100 liquid chromatograph with a Waters X-Bridge Prep Shield RP18 (10×150 mm) column. Column chromatography (CC) was performed using silica gel (100-200 mesh and 300-400 mesh, Qingdao 
Marine Chemical, Inc., Qingdao, P. R. China) and Sephadex LH-20 (40-70 $\mu \mathrm{m}$, Amersham Pharmacia Biotech AB, Uppsala, Sweden).

\subsection{Plant Material}

The twigs and stems of M. effusum were collected from Guangxi Province, People's Republic of China, in November 2014. The plant samples were identified by Ligong Lei of Kunming Institute of Botany, Chinese Academy of Science (CAS). A voucher specimen (HXJ20141101) was deposited at the State Key Laboratory of Phytochemistry and Plant Resource in West China, Kunming Institute of Botany, Chinese Academy of Science (CAS).

\subsection{Extraction and Isolation}

The air-dried, powdered leaves and twigs (57 kg) of M. effusum were extracted three times with $\mathrm{MeOH}$ at room temperature. The total extract $(4.8 \mathrm{~kg})$ was subjected to normal phase Si gel (100-200 mesh; $\mathrm{CHCl}_{3} / \mathrm{MeOH}, 1: 0$ to $0: 1$ ) to obtain four major fractions (Fr. 1-4). Fraction 3 (212.3 g) was once again subjected to Si gel column chromatography (300-400 mesh) with $\mathrm{CHCl}_{3} / \mathrm{MeOH}$ (15:1) to yield six sub-fractions (3a-3f). Fraction 3a (211.4 mg) was chromatographed over a sephadex LH-20 gel column, and then separated by semi-preparative HPLC (Waters XSelect Hss T3, 5 $\mu \mathrm{m}, 10 \times 150 \mathrm{~mm}$; $\mathrm{MeOH}-\mathrm{H}_{2} \mathrm{O}, 35: 65$; velocity of flow $2.5 \mathrm{~mL} / \mathrm{min})$ to give compound $1\left(13.8 \mathrm{mg}\right.$, retention time $\left.\left(\mathrm{t}_{R}\right)=27.5 \mathrm{~min}\right)$. Similarly, fraction $3 \mathrm{e}(96 \mathrm{mg})$ was separated to give compound $\mathbf{3}\left(1.8 \mathrm{mg}, \mathrm{t}_{R}=20 \mathrm{~min}\right)$ by semi-preparative HPLC (Waters T3 column; MeOH- $\mathrm{H}_{2} \mathrm{O}, 23: 77$; velocity of flow $2.0 \mathrm{~mL} / \mathrm{min}$ ). Fraction 3d (95 mg) was directly chromatographed over a sephadex LH-20 gel column to give compound 2 (15.2 mg). Fraction 2 (311.5 g) was also subjected to $\mathrm{Si}$ gel column chromatography with $\mathrm{CHCl}_{3} / \mathrm{MeOH}(20: 1)$ to yield four sub-fractions (2a-2d). Fraction 2c (90.0 g) was chromatographed over a RP-C18 silica gel with step-gradient of 
$\mathrm{MeOH}-\mathrm{H}_{2} \mathrm{O}(\mathrm{v} / \mathrm{v}$, from 10:90 to 90:10) to obtain the crude alkaloids (51.4 g) and then separated to three fractions (2c-1-2c-3) by Si gel column chromatography (300-400 mesh, $\left.\mathrm{CHCl}_{3} / \mathrm{MeOH}, 20: 1\right)$. Fraction $2 \mathrm{c}-1$ (12.6 g) was separated by preparative HPLC (Waters XSelect CSH prep C18, $5 \mu \mathrm{m}, 19 \times 150 \mathrm{~mm}$; $\mathrm{MeOH}-\mathrm{H}_{2} \mathrm{O}$, from 30:70 to 90:10 in 20 mins; velocity of flow $10 \mathrm{~mL} / \mathrm{min}$ ) to obtained three fractions (2c-1a-2c-1c).

Fraction 2c-1b (1.4 g) was chromatographed over a sephadex LH-20 gel column to give six fractions (2c-1b-1-2c-1b-6). Fraction 2c-1b-6 was separated by semi-preparative HPLC (Waters X Bridge prep shield $\left.\mathrm{RP} 18,5 \mu \mathrm{m}, 10 \times 150 \mathrm{~mm} ; \mathrm{MeCN}_{-} \mathrm{H}_{2} \mathrm{O}, 17: 83\right)$ to give compound 4 (3.1 mg, $\left.\mathrm{t}_{R}=28 \mathrm{~min}\right)$. Similarly, 5 (4.7 g) and $7(38.5 \mathrm{mg})$ were obtained from fraction $2 \mathrm{c}-1 \mathrm{~b}$ and $6(1.0 \mathrm{mg})$ was obtained from fraction $2 \mathrm{c}-1 \mathrm{c}$.

\section{4 mysumamide A (1)}

Colorless crystal. $[\alpha]_{\mathrm{D}}^{24}=-50.1(c=0.21, \mathrm{MeOH}) . \mathrm{UV}(\mathrm{MeOH}): 204$ (3.93). IR (KBr): 3427, 2925, 2861, $1643,1455,1443,1418,1372,1334,1295,1241,1195,1179,1089$ and $1026 \mathrm{~cm}^{-1} .{ }^{1} \mathrm{H}$ and ${ }^{13} \mathrm{C}$ NMR data (see Tables 1 and 2). Positive ESIMS: $m / z, 249[\mathrm{M}+\mathrm{H}]^{+}$. Positive HRESIMS: $[\mathrm{M}+\mathrm{H}]^{+} \mathrm{m} / z$ 249.1962, calcd 249.1961. Melting point: $128-130{ }^{\circ} \mathrm{C}$.

\section{5 mysumamide $B(2)$}

Colorless oil. $[\alpha]_{\mathrm{D}}^{25}=+6.8(c=0.39, \mathrm{MeOH})$. UV (MeOH): 204 (3.82). IR (KBr): 3426, 2931, 2865, 1664, $1443,1419,1369,1333,1295,1260,1184,1162,1088,1054,1011$ and $976 \mathrm{~cm}^{-1} .{ }^{1} \mathrm{H}$ and ${ }^{13} \mathrm{C}$ NMR data (see Tables 1 and 2). Positive ESIMS: $m / z 265[\mathrm{M}+\mathrm{H}]^{+}$. Positive HRESIMS: $[\mathrm{M}+\mathrm{H}]^{+} m / z$ 265.1914, calcd 265.1911.

\section{6 mysumamide $C(\mathbf{3})$}

Colorless oil. $[\alpha]_{\mathrm{D}}^{24}=-12.9(c=0.12, \mathrm{MeOH}) . \mathrm{UV}(\mathrm{MeOH}): 380$ (1.68), 204 (3.67). IR (KBr): 3426, 2926, 2854, 1632, 1447, 1418, 1384, 1291, 1272, 1234, 1201, 1175, 1121, 1087, 1064 and $1035 \mathrm{~cm}^{-1} .{ }^{1} \mathrm{H}$ and ${ }^{13} \mathrm{C}$ 
NMR data (see Tables 1 and 2). Positive ESIMS: $m / z 265[\mathrm{M}+\mathrm{H}]^{+}$. Positive HRESIMS: $[\mathrm{M}+\mathrm{H}]^{+} \mathrm{m} / z$ 265.1911, calcd 265.1911.

\section{7 mysumamide $D(4)$}

Colorless oil. $[\alpha]_{\mathrm{D}}^{19}=+38.6(c=0.46, \mathrm{MeOH}) . \mathrm{UV}(\mathrm{MeOH}): 204(3.76)$; IR $(\mathrm{KBr}): 3420,2930,2858$, $1633,1448,1420,1377,1323,1299,1226,1204,1173,1058$, and $1026 \mathrm{~cm}^{-1} \cdot{ }^{1} \mathrm{H}$ and ${ }^{13} \mathrm{C}$ NMR data (see Tables 1 and 2). Positive ESIMS: $m / z 279[\mathrm{M}+\mathrm{H}]^{+}$; Positive HRESIMS: $[\mathrm{M}+\mathrm{H}]^{+} m / z$ 279.2066, calcd 279.2067.

\section{Results and discussion}

Mysumamide A (1) was obtained as colorless crystal, and its molecular formula $\mathrm{C}_{15} \mathrm{H}_{24} \mathrm{~N}_{2} \mathrm{O}$ was established by positive HRESIMS $\left(m / z 249.1962[\mathrm{M}+\mathrm{H}]^{+}\right.$, calcd for $\left.\mathrm{C}_{15} \mathrm{H}_{25} \mathrm{~N}_{2} \mathrm{O}, 249.1961\right)$, corresponding to 5 degrees of unsaturation. The IR absorption band at $1643 \mathrm{~cm}^{-1}$ showed the presence of carbonyl functionality. Analysis of the NMR data, including DEPT and HSQC spectra revealed the presence of 15 carbon resonances, corresponding to one amide carbonyl ( $\left.\delta_{\mathrm{C}} 170.6\right)$, ten $\mathrm{sp}^{3}$ methylenes, and four $\mathrm{sp}^{3}$ methines (Table 2$)$. Of these, one methine $\left(\delta_{\mathrm{C}} 75.5\right)$ was typical carbon bearing two nitrogen atoms of Myrioneuron alkaloid; two methylenes $\left(\delta_{\mathrm{C}} 38.6\right.$ and 47.6$)$ and one methine $\left(\delta_{\mathrm{C}} 65.3\right)$ were representative carbons bearing one nitrogen atom, respectively. The amide carbonyl accounted for one out of the five indices of hydrogen deficiency, requiring four rings in the structure.

The gross structure of 1 was constructed by 2D NMR experiment as a myrionamide-type alkaloid. Analysis of the ${ }^{1} \mathrm{H}-{ }^{1} \mathrm{H}$ COSY and HSQC spectra revealed two structural fragments as drawn with bold bonds (Figure 2). The connectivity of the both structural fragments, nitrogen atoms and the carbonyl group was then established by the analysis of HMBC correlations. Particularly, the HMBC correlations of $\mathrm{H}_{2}-2\left(\delta_{\mathrm{H}} 2.46, \mathrm{td}, 14.6,4.0\right)$ and 
$\mathrm{H}-10\left(\delta_{\mathrm{H}} 2.67, \mathrm{dd}, 13.8,5.7\right)$ to $\mathrm{C}-13\left(\delta_{\mathrm{C}} 75.5\right)$ indicated that $\mathrm{C}-2\left(\delta_{\mathrm{C}} 38.6\right), \mathrm{C}-10\left(\delta_{\mathrm{C}} 65.3\right)$, and C-13 were connected via $\mathrm{N}-1$; the HMBC correlations of $\mathrm{H}_{2}-11\left(\delta_{\mathrm{H}} 2.21, \mathrm{t}, 15.3\right)$ with C-13 revealed that C-11 $\left(\delta_{\mathrm{C}} 47.6\right)$ and $\mathrm{C}-13$ were connected through $\mathrm{N}-12$. In addition, the chemical shifts and HMBC correlations from $\mathrm{H}-13\left(\delta_{\mathrm{H}}\right.$ 4.41, t, 8.55), $\mathrm{H}_{2}-16\left(\delta_{\mathrm{H}} 2.29, \mathrm{dd}, 9.5,7.3\right)$ and $\mathrm{H}_{2}-11\left(\delta_{\mathrm{H}} 4.61, \mathrm{dd}, 13.8,5.7\right)$ to $\mathrm{C}-17\left(\delta_{\mathrm{C}} 170.6\right)$ indicated the presence of a carbonyl at C-17. Thus, the 2D structure of $\mathbf{1}$ was established as shown.

The structure and the relative configuration of $\mathbf{1}$ were further confirmed by X-ray crystallographic analysis. The ORTEP drawing, with the atom-numbering indicated, was shown in Figure 3. In the crystal structure, all four rings adopted chair conformation. Then, the absolute configuration of $\mathbf{1}$ was unequivocally established as 5S, 9S, 10R, 13R via the refinement of its $\mathrm{Cu} \mathrm{K \alpha}$ data [Flack parameter: 0.0 (3)].

The molecular formula of Mysumamide B (2) was established as $\mathrm{C}_{15} \mathrm{H}_{24} \mathrm{~N}_{2} \mathrm{O}_{2}$ by positive HRESIMS $(\mathrm{m} / \mathrm{z}$ 265.1914 $[\mathrm{M}+\mathrm{H}]^{+}$, calcd for $\mathrm{C}_{15} \mathrm{H}_{25} \mathrm{~N}_{2} \mathrm{O}_{2}, 265.1911$ ) with five degrees of unsaturation. Comparison of the NMR data of $\mathbf{2}$ to those of $\mathbf{1}$ (Tables 1 and 2) showed that they were closely related analogues featuring identical carbon frameworks. The main distinction was that the carbon signals of C-2, C-10 and C-13 in 2 were shifted downfield by 12.1, 14.7, $12.8 \mathrm{ppm}$, respectively. All these data suggested that these three carbons should be attached to the N-oxide group, which was further confirmed by 2D-NMR experiments. The relative configurations of all the chiral carbons of $\mathbf{2}$ was consistent with those of $\mathbf{1}$ as determined by similar ROESY correlations. Moreover, by comparison of the NMR data of 2 with that of $\mathbf{1}$, the resonance of the C-5 is $6.0 \mathrm{ppm}$ to low frequency $\left(\Delta \delta_{\mathrm{C}-5}=-6.0 \mathrm{ppm}\right)$, which indicated that the oxygen atom at $\mathrm{N}-1$ adopted $\beta$ configuration as same as H-5 due to the obvious $\gamma$-gauche effect. [14-15]

Mysumamide C (3) was obtained as colorless oil. Its molecular formula, $\mathrm{C}_{15} \mathrm{H}_{24} \mathrm{~N}_{2} \mathrm{O}_{2}$, was established by HRESIMS $\left(m / z, 265.1911[\mathrm{M}+\mathrm{H}]^{+}\right.$, calcd for $\left.\mathrm{C}_{15} \mathrm{H}_{25} \mathrm{~N}_{2} \mathrm{O}_{2}, 265.1911\right)$, which had one more oxygen atom 
than that of 5. By comparing their NMR data (Tables 1 and 2), 3 were suggested to be the N-oxide derivatives of 5. Subsequent 2D NMR data analyses defined its structure as myrionamide N-12-oxide. The relative configuration of $\mathbf{3}$ was shown to be identical to that of $\mathbf{5}$ based on their similar coupling constants and supported by the NOESY data. The up-field shift of the C-9 carbon $\left(\Delta \delta_{\mathrm{C}-9}=-5.9 \mathrm{ppm}\right)$ compared with that of 5 revealed that oxygen atom at $\mathrm{N}-12$ adopted $\alpha$ configuration as same as $\mathrm{H}-9$ due to the $\gamma$-gauche effect.

Mysumamide D (4) was assigned the molecular formula $\mathrm{C}_{16} \mathrm{H}_{26} \mathrm{~N}_{2} \mathrm{O}_{2}$ by HRESIMS at $m / z$ 279.2066 [M $+\mathrm{H}]^{+}$(calcd for $\mathrm{C}_{16} \mathrm{H}_{27} \mathrm{~N}_{2} \mathrm{O}_{2}, 279.2067$ ), corresponding to five indices of hydrogen deficiency. Analysis of the NMR data (Tables 1 and 2), including DEPT and HSQC data of compound 4 revealed the presence of 16 carbon signals comprising one lactam carbonyl $\left(\delta_{\mathrm{C}} 168.3\right)$, ten $\mathrm{sp}^{3}$ methylenes (one oxygenated, and one nitrogenated), and five $\mathrm{sp}^{3}$ methines (three nitrogenated). In addition to the one indice of hydrogen deficiency accounting for the lactam moiety, the remaining four indices of hydrogen deficiency were assumed to be due to the presence of a tetracyclic system in $\mathbf{4}$. The ${ }^{1} \mathrm{H}$ and ${ }^{13} \mathrm{C}$ NMR data of compound $\mathbf{4}$ resembled those of $\mathbf{5}$, indicating that both compounds are analogues. The main distinction was attributable to the presence of one additional hydroxymethyl $\left(\mathrm{C}-18, \delta_{\mathrm{C}} 58.1\right)$ in the former. ${ }^{1} \mathrm{H}^{-}{ }^{1} \mathrm{H}$ COSY correlation of $\mathrm{H}_{2}-18\left(\delta_{\mathrm{H}} 3.75, \mathrm{dd}, 11.5\right.$, $\left.3.7 ; \delta_{\mathrm{H}} 3.63, \mathrm{dd}, 11.5,2.1\right) / \mathrm{H}-11\left(\delta_{\mathrm{H}} 2.76, \mathrm{dd}, 11.2,5.2\right)$ suggested that the hydroxymethyl located at $\mathrm{C}-11\left(\delta_{\mathrm{C}}\right.$ 59.1), which was further confirmed by the HMBC correlations of $\mathrm{H}_{2}-18$ to $\mathrm{C}-9\left(\delta_{\mathrm{C}} 38.0\right)$ and C-11. ROESY correlations of $\mathrm{H}-10\left(\delta_{\mathrm{H}} 3.47, \mathrm{dd}, 11.2,5.2\right) / \mathrm{H}-11$ and $\mathrm{H}-10 / \mathrm{H}-13\left(\delta_{\mathrm{H}} 5.39, \mathrm{dd}, 11.2,2.8\right)$, and the correlations of $\mathrm{H}-6 \beta\left(\delta_{\mathrm{H}} 1.70, \mathrm{~m}\right) / \mathrm{H}-5\left(\delta_{\mathrm{H}} 2.10, \mathrm{dt}, 16.1,5.2\right)$ and $\mathrm{H}-6 \beta / \mathrm{H}-10$, indicated that these protons were cofacial as $\beta$-oriented (Figure 4). Therefore, the structure of $\mathbf{4}$ was determined as shown.

Biogenetically, mysumamide D (4) should be derived from the deoxide (8) of mysumamide C as described in Scheme 1.8 could be transformed into intermediate 9 via oxidation and dehydration. Then, intermolecular aldol 
condensation between 9 and formaldehyde yields intermediate 10. Finally, compound 4 was generated by selective reduction.

Compounds 1-7 had been tested for their cytotoxicity against Hela, MCF-7, A549, MGC-803, and COLO-205 human cancer cell lines in vitro. The results indicated that only compound $\mathbf{5}$ exhibited weak cytotoxic activity against Hela, A549, and COLO-205 cell lines with $\mathrm{IC}_{50}$ of $38.3,35.2$, and $38.7 \mu \mathrm{M}$, respectively.

\section{Acknowledgments}

This research was supported financially by grants from the National Science Foundation of China (21432010, 21372228), Technological leading talent project of Yunnan (2015HA020), Central Asian Drug Discovery and Development Center of Chinese Academy of Sciences (CAM201402 and CAM201302), Young Academic and Technical Leader Foundation of Yunnan Province (to Ying-Tong Di), and the Xibuzhiguang Project (grant to Ying-Tong Di). The Syngenta postgraduate studentship awarded to Jia-Hui Zhang (2014-2016) is appreciated. We are grateful to Dr. Xiao-Nian Li (Kunming Institute of Botany, Chinese Academy of Sciences) for the help in X-ray diffraction analysis. 


\section{Refferences}

[1] Pham VC, Jossang A, Chiaroni A, Sévenet T, Bodo B. Asymmetric synthesis of myrioxazines A and B, novel alkaloids of Myrioneuron nutans. Tetrahedron Lett 2002; 43:7565-7568

[2] Pham VC, Jossang A, Chiaroni A, Sévenet T, Nguyen VH, Bodo B. Solution and crystal conformations of myrionine, a new 8beta-alkyl-cis-decahydroquinoline of Myrioneuron nutans. Org lett 2007; 9:3531-3534

[3] Pham VC, Jossang A, Sévenet T, Nguyen VH, Bodo B. Absolute configuration of myrobotinol, new fused-hexacyclic alkaloid skeleton from Myrioneuron nutans. J Org Chem 2007; 72:9826-9829

[4] Pham VC, Jossang A, Sévenet T, Nguyen VH, Bodo B. Myrioneurinol: a novel alkaloid skeleton from Myrioneuron nutans. Tetrahedron 2007; 63:11244-11249

[5] Pham VC, Jossang A, Grellier P, Sévenet T, Nguyen VH, Bodo B. Structure and total synthesis of (-)-myrionidine and (-)-schoberine, antimalarial alkaloids from Myrioneuron nutans. J Org Chem 2008; $73: 7565-7573$

[6] Pham VC, Jossang A, Sévenet T, Nguyen VH, Bodo B. Novel Alkaloids fromMyrioneuron nutans. Eur J Org Chem 2009;1412-1416

[7] Huang SD, Zhang Y, Cao MM, Di YT, Tang GH, Peng ZG, et al. Myriberine A, a new alkaloid with an unprecedented heteropentacyclic skeleton from Myrioneuron faberi. Org lett 2013; 15:590-593

[8] Cao MM, Huang SD, Di YT, Yuan CM, Zuo GY, Gu YC, et al. Myrifabine, the first dimeric Myrioneuron alkaloid from Myrioneuron faberi. Org lett 2014; 16:528-531

[9] Cao MM, Zhang Y, Li XH, Peng ZG, Jiang JD, Gu YC, et al. Cyclohexane-fused octahydroquinolizine alkaloids from Myrioneuron faberi with activity against hepatitis C virus. J Org Chem 2014; 79:7945-7950

[10] Cao MM, Zhang Y, Huang SD, Di YT, Peng ZG, Jiang JD, et al. Alkaloids with Different Carbon Units from Myrioneuron faberi. J Nat Prod 2015; 78:2609-2616 
[11] Li XH, Zhang Y, Zhang JH, Li XN, Cao MM, Di YT, et al. Myritonines A-C, Alkaloids from Myrioneuron tonkinensis based on a novel hexacyclic skeleton. J Nat Prod 2016; 79:1203-1207

[12] Cao MM, Zhang Y, Peng ZG, Jiang JD, Gao YJ, Hao XJ. Schoberine B, an alkaloid with an unprecedented straight C5 side chain, and myriberine B from Myrioneuron faberi. RSC Adv 2016; 6:10180-10184

[13] Song DP, Wang ZS, Mei RM, Zhang WW, Ma DH, Xu DY, et al. Short and scalable total synthesis of Myrioneuron alkaloids ( \pm )- $\alpha, \beta$-myrifabral A and B. Org lett 2016; 18:669-671

[14] Barfield M, Yamamura SH. Ab initio IGLO studies of the conformational dependencies of $\alpha-, \beta-$, and $\gamma$-substituent effects in the ${ }^{13} \mathrm{C}$ NMR Spectra of aliphatic and alicyclic hydrocarbons. J Am Chem Soc 1990; 112:4747-4758

[15] Zhang W, GUO YW, Krohn K. Macropodumines A-C: novel pentacyclic alkaloids with an unusual skeleton or zwitterion moiety from Daphniphyllum macropodum Miq. Chem Eur J 2006; 12:5122-5127 
Table 1. ${ }^{1} \mathrm{H}$ NMR Spectroscopic Data for 1 to 4.

\begin{tabular}{|c|c|c|c|c|}
\hline position & $\mathbf{1}^{a}$ & $2^{a}$ & $\mathbf{3}^{b}$ & $4^{b}$ \\
\hline \multirow[t]{2}{*}{2} & $2.78(\mathrm{dt}, 13.7,3.9)$ & $3.08(\mathrm{~m})$ & - & - \\
\hline & $2.46(\mathrm{td}, 14.6,4.0)$ & $3.01(\mathrm{~m})$ & & \\
\hline \multirow[t]{2}{*}{3} & $1.78(\mathrm{~m})$ & $1.68(\mathrm{~m})$ & $2.70(\mathrm{dd}, 18.0,4.8)$ & $2.49(\mathrm{ddd}, 17.6,5.3,1.6)$ \\
\hline & $1.54(\mathrm{~m})$ & $1.54(\mathrm{~m})$ & $2.38(\mathrm{dd}, 11.9,6.2)$ & $2.36(\mathrm{ddd}, 17.6,12.8,6.7)$ \\
\hline \multirow[t]{2}{*}{4} & $1.93(\mathrm{~m})$ & $2.39(\mathrm{~m})^{\mathrm{c}}$ & $2.21(\mathrm{ddd}, 26.5,13.0,4.9)$ & $1.99(\mathrm{ddd}, 26.1,13.0,5.3)$ \\
\hline & $1.31(\mathrm{~m})$ & $1.69(\mathrm{~m})$ & $1.50(\mathrm{~m})$ & $1.48(\mathrm{~m})^{\mathrm{c}}$ \\
\hline 5 & $1.92(\mathrm{~m})$ & $1.73(\mathrm{~m})$ & $2.11(\mathrm{~m})^{\mathrm{c}}$ & $2.10(\mathrm{dt}, 16.1,5.2)$ \\
\hline \multirow[t]{2}{*}{6} & $1.55(\mathrm{~m})$ & $2.94(\mathrm{~m})$ & $1.80(\mathrm{~m})$ & $1.70(\mathrm{~m})$ \\
\hline & $1.42(\mathrm{~m})$ & $0.99(\mathrm{~m})^{\mathrm{c}}$ & $1.66(\mathrm{~m})$ & $1.41(\mathrm{~m})^{\mathrm{c}}$ \\
\hline \multirow[t]{2}{*}{7} & $1.56(\mathrm{~m})$ & $1.58(\mathrm{dd}, 13.5,4.3)$ & $1.55(\mathrm{~m})$ & $1.58(\mathrm{~m})$ \\
\hline & $1.39(\mathrm{~m})$ & $1.37(\mathrm{~m})$ & $1.46(\mathrm{~m})$ & $1.41(\mathrm{~m})^{\mathrm{c}}$ \\
\hline \multirow[t]{2}{*}{8} & $1.60(\mathrm{~m})$ & $1.48(\mathrm{~m})$ & $0.96(\mathrm{dd}, 25.0,12.1,3.4)$ & $1.81(\mathrm{~m})$ \\
\hline & $0.85(\mathrm{~m})$ & $0.99(\mathrm{~m})^{\mathrm{c}}$ & $1.58(\mathrm{~m})$ & $1.02(\mathrm{ddd}, 25.3,12.8,3.5)$ \\
\hline 9 & $2.05(\mathrm{~m})$ & $2.06(\mathrm{ddt}, 23.5,11.7,4.2)$ & $2.91(\mathrm{~m})^{\mathrm{c}}$ & $1.77(\mathrm{~m})$ \\
\hline 10 & $2.67(\mathrm{dd}, 13.8,5.7)$ & $3.05(\mathrm{~m})$ & $3.31(\mathrm{dd}, 11.2,5.3)$ & $3.47(\mathrm{dd}, 11.2,5.2)$ \\
\hline \multirow[t]{2}{*}{11} & $4.61(\mathrm{dd}, 16.0,5.8)$ & $4.71(\mathrm{dd}, 13.2,4.7)$ & $3.40(\mathrm{t}, 11.3)$ & $2.76(\mathrm{dd}, 11.2,5.2)$ \\
\hline & $2.21(\mathrm{t}, 15.3)$ & $2.39(\mathrm{~m})^{\mathrm{c}}$ & $2.91(\mathrm{~m})^{\mathrm{c}}$ & \\
\hline 13 & $4.41(\mathrm{t}, 8.6)$ & $4.62(\mathrm{dd}, 7.7,4.8)$ & $5.78(\mathrm{dd}, 12.9)$ & $5.39(\mathrm{dd}, 11.2,2.8)$ \\
\hline \multirow[t]{2}{*}{14} & $1.96(\mathrm{~m})$ & $2.62(\mathrm{~m})$ & $2.11(\mathrm{~m})^{\mathrm{c}}$ & $1.48(\mathrm{~m})^{\mathrm{c}}$ \\
\hline & $1.63(\mathrm{~m})^{\mathrm{c}}$ & $2.31(\mathrm{dd}, 12.0,4.4)$ & $1.84(\mathrm{~m})^{\mathrm{c}}$ & $1.86(\mathrm{~m})$ \\
\hline \multirow[t]{2}{*}{15} & $1.81(\mathrm{~m})$ & $1.84(\mathrm{~m})$ & $1.95(\mathrm{~d}, 12.1)$ & $1.29(\mathrm{~m})$ \\
\hline & $1.63(\mathrm{~m})^{\mathrm{c}}$ & $1.72(\mathrm{~m})$ & $1.73(\mathrm{~m})^{\mathrm{c}}$ & $1.68(\mathrm{dt}, 18.2,4.5)$ \\
\hline \multirow[t]{2}{*}{16} & $2.29(\mathrm{dd}, 9.5,7.3)$ & $2.36(\mathrm{dd}, 7.4,2.2)$ & $1.84(\mathrm{~m})^{\mathrm{c}}$ & $1.30(\mathrm{~m})$ \\
\hline & $1.82(\mathrm{~m})$ & $1.85(\mathrm{~m})$ & $1.73(\mathrm{~m})^{\mathrm{c}}$ & $1.48(\mathrm{~m})^{\mathrm{c}}$ \\
\hline \multirow[t]{2}{*}{17} & - & - & $3.52(\mathrm{dd}, 6.8)$ & $3.18(\mathrm{~d}, 13.9)$ \\
\hline & & & $3.64(\mathrm{~m})$ & $2.80(\mathrm{td}, 13.2,2.7)$ \\
\hline \multirow[t]{2}{*}{18} & & & & $3.75(\mathrm{dd}, 11.5,3.7)$ \\
\hline & & & & $3.63(\mathrm{dd}, 11.5,2.1)$ \\
\hline
\end{tabular}

\footnotetext{
${ }^{a}$ Recorded in $\mathrm{CDCl}_{3}-d_{1}$ at $500 \mathrm{MHz} . \quad{ }^{b}$ Recorded in $\mathrm{CDCl}_{3}-d_{1}$ at $600 \mathrm{MHz}$.
}

${ }^{c}$ Overlapped. 
Table2. ${ }^{13} \mathrm{C}$ NMR Spectroscopic Data for 1 to 4.

\begin{tabular}{|c|c|c|c|c|}
\hline position & $1^{\mathrm{a}}$ & $2^{\mathrm{a}}$ & $3^{\mathrm{b}}$ & $4^{b}$ \\
\hline 2 & 38.6 & 50.7 & 170.4 & 168.3 \\
\hline 3 & 25.8 & 30.3 & 32.9 & 32.6 \\
\hline 4 & 24.1 & 20.0 & 21.6 & 21.7 \\
\hline 5 & 35.3 & 29.3 & 32.7 & 33.0 \\
\hline 6 & 20.0 & 29.3 & 30.5 & 30.3 \\
\hline 7 & 31.2 & 22.0 & 20.1 & 20.6 \\
\hline 8 & 29.7 & 19.4 & 28.1 & 29.3 \\
\hline 9 & 26.3 & 31.6 & 31.3 & 38.0 \\
\hline 10 & 65.3 & 80.0 & 55.4 & 54.4 \\
\hline 11 & 47.6 & 46.9 & 62.6 & 59.1 \\
\hline 13 & 75.5 & 88.3 & 79.0 & 66.4 \\
\hline 14 & 26.2 & 20.8 & 26.5 & 24.8 \\
\hline 15 & 19.3 & 18.4 & 22.7 & 20.2 \\
\hline 16 & 32.9 & 32.1 & 23.1 & 24.4 \\
\hline 17 & 170.6 & 170.1 & 70.2 & 48.9 \\
\hline $\mathrm{CH}_{2} \mathrm{OH}$ & & & & 58.1 \\
\hline
\end{tabular}

${ }^{\text {a }}$ Recorded in $\mathrm{CDCl}_{3}-d_{1}$ at $125 \mathrm{MHz}$.

${ }^{\mathrm{b}}$ Recorded in $\mathrm{CDCl}_{3}-d_{1}$ at $150 \mathrm{MHz}$. 

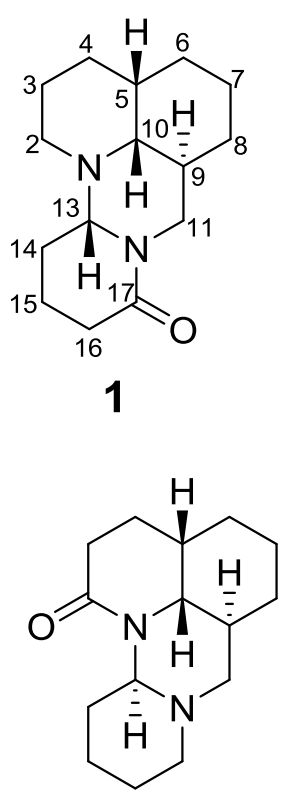

5
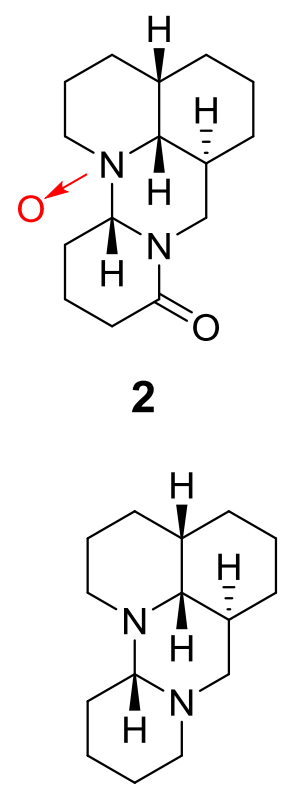

6

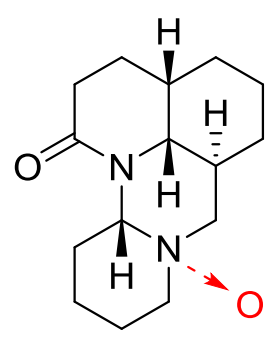

3

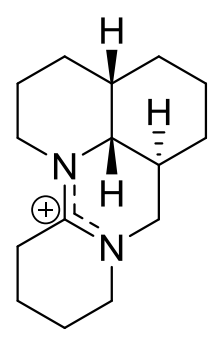

7

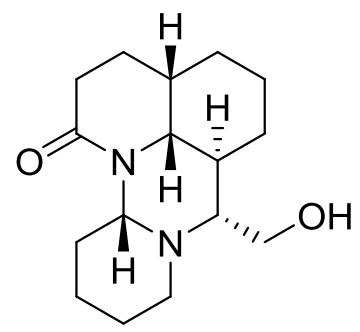

4

Figure 1. Structures of 1 to 7. 


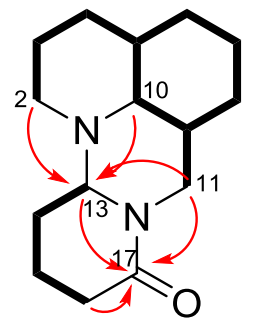

A

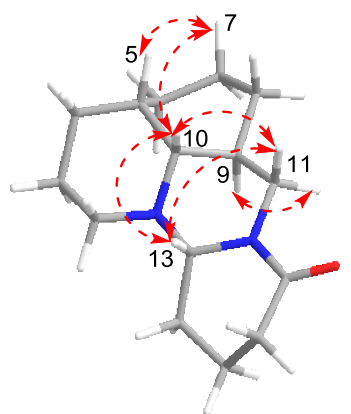

B

Figure 2. (A) ${ }^{1} \mathrm{H}^{-1} \mathrm{H}$ COSY (Bold) and Key HMBC Correlations (Arrow, H $\rightarrow$ C) of 1. (B) Key ROESY Correlations of 1. 


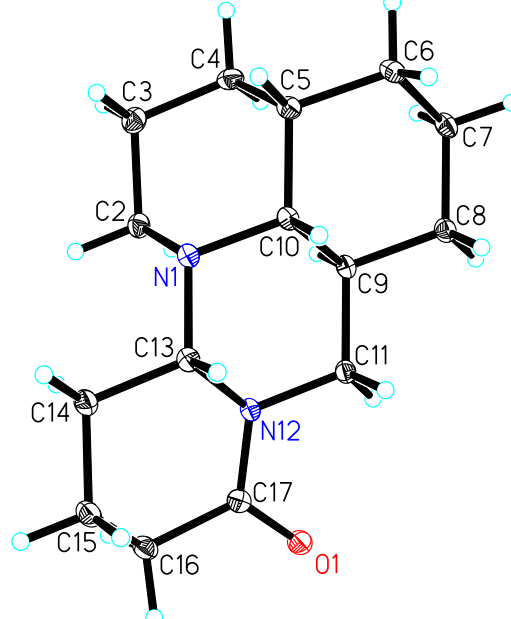

Figure 3. X-ray ORTEP drawing of compound 1. 


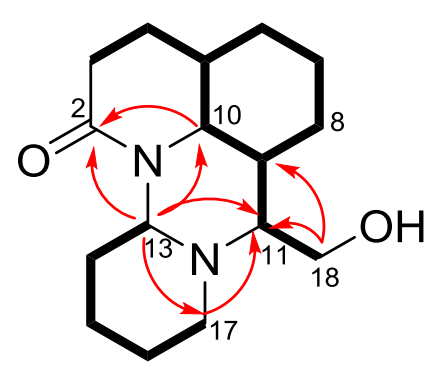

A

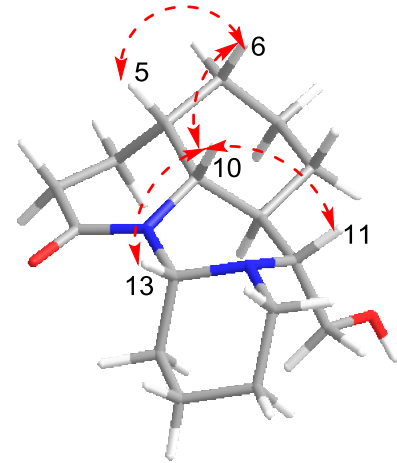

B

Figure 4. (A) ${ }^{1} \mathrm{H}^{-1} \mathrm{H}$ COSY (Bold) and Key HMBC Correlations (Arrow, H $\rightarrow$ C) of 4. (B) Key ROESY Correlations of 4. 
Scheme 1. Plausible Biogenetic Pathway of 4.

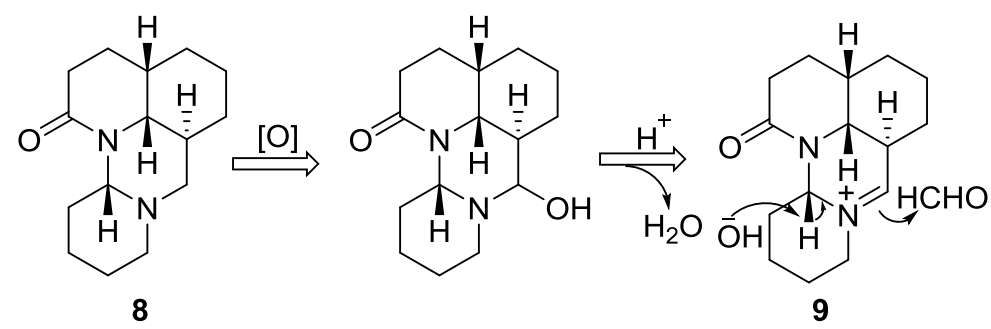

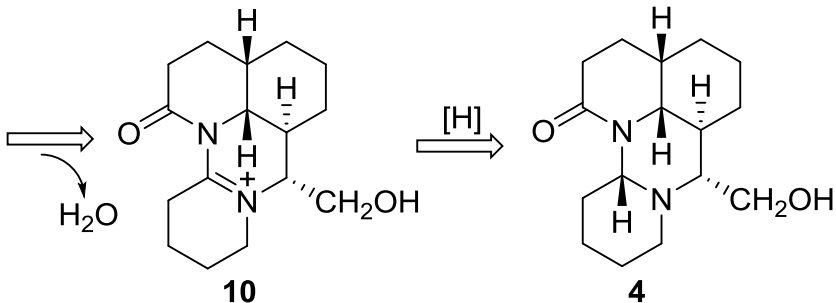



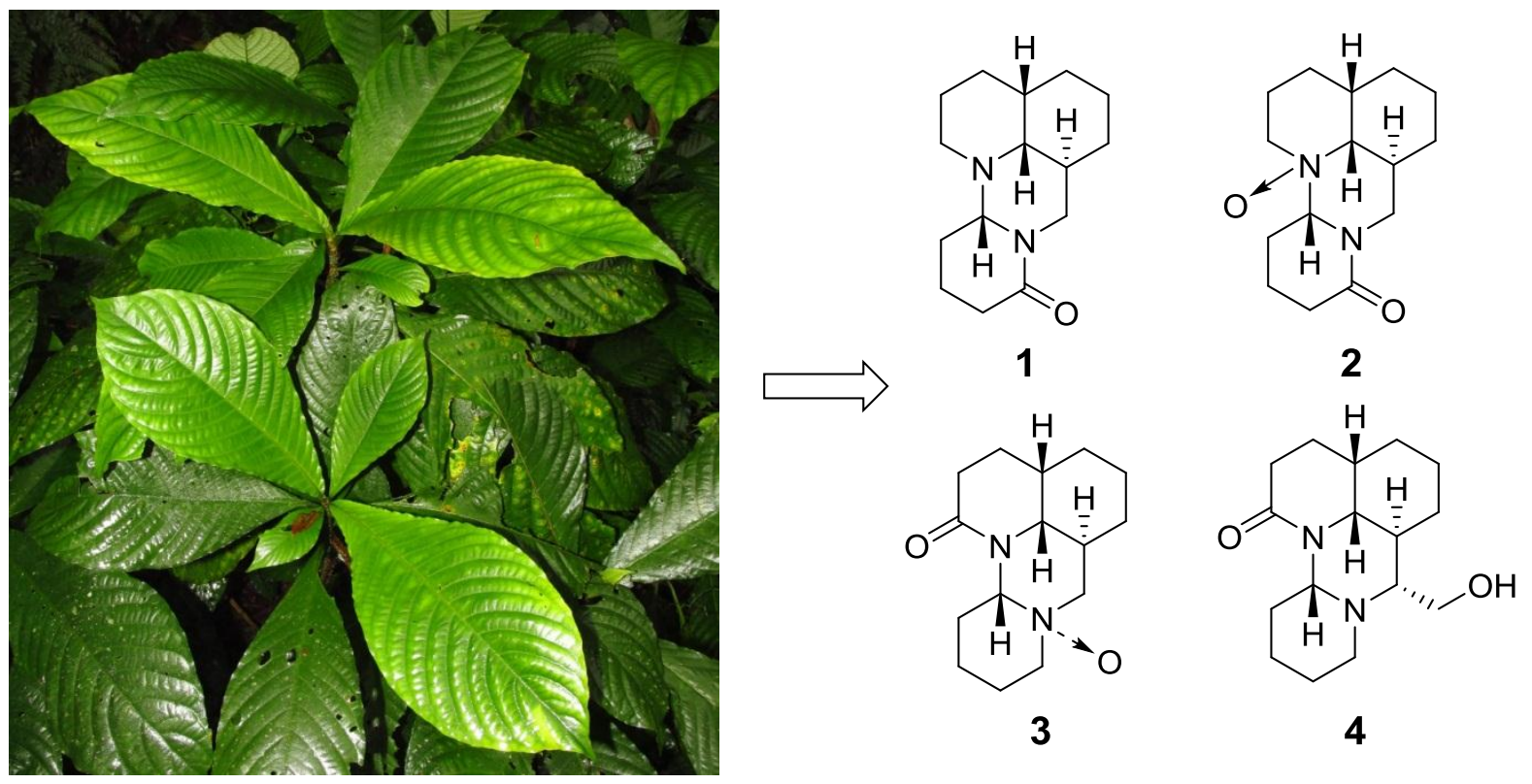